\title{
Hepatotoxic and Nephrotoxic Effect of Ethanol Leaf Extract of Scoparia Dulcis (Linn) in Wistar Rats
}

\author{
Olubodun A. Adebiyi, Danladi A. Ameh, Elewechi Onyike, and Dorcas B. James
}

\section{ABSTRACT}

Scoparia dulcis (Linn) is a widespread herbal medicine; it bears an enormous number of pharmacological activities. The present study was undertaken to find out the chronic toxicity profile of oral administration of Scoparia dulcis ethanol leaf extract (SDELE) on the liver and the kidney of wistar rats. The animals were grouped into four and administered varying doses of SDELE $(100 \mathrm{mg} / \mathrm{kg}, 200 \mathrm{mg} / \mathrm{kg}, 400 \mathrm{mg} / \mathrm{kg}$ body weight and $0.2 \mathrm{ml}$ distilled water respectively) for a period of fourteen weeks (100 days). The acute toxicity, body weight, relative organ weight, hematological parameters, biochemical markers for liver and kidney damage were monitored and histopathology of the liver and kidney of the rat were carried out. The $\mathrm{LD}_{50}$ of SDELE was found to be $1131 \mathrm{mg} / \mathrm{kg}$ body weight. There was a significant $(p<0.05)$ reduction in weight of the rat administered $400 \mathrm{mg} / \mathrm{kg}$ and $200 \mathrm{mg} / \mathrm{kg}$ when compared with the control though there was no significant difference $(p>0.05)$ in the relative weight of the organs. There was also a significant increase $(p<0.05)$ in the lymphocytes, serum level of aspartate amino transferase (ASP), alanine amino transferase (ALT), alkali phosphatase (ALP), total protein, A/G ratio, creatinine, urea, uric acid, total cholesterol, triacylglycerol, low density lipoprotein cholesterol and potassium ions while there was a significant decrease in HDL-cholesterol and sodium ions in the animal group administered $400 \mathrm{mg} / \mathrm{kg}$ body weight of the extract. Histopathology of the liver and kidney revealed haemorrhage and vascular congestion at $200 \mathrm{mg} / \mathrm{kg}$ doses and renal damage at $400 \mathrm{mg} / \mathrm{kg}$ body weight doses respectively. However, there was no significant difference $(p>0.05)$ in any of the parameters studied in the group administered $100 \mathrm{mg} / \mathrm{kg}$ body weight dose when compared with the controlled group. Ethanol leaf extracts of Scoparia dulcis showed hepatotoxic and nephrotoxic tendencies and should be used with caution especially when employed in the treatment of chronic diseases.

Keywords: Chronic toxicity, Hepatotoxic, Nephrotoxic, Scoparia dulcis (Linn).

\section{INTRODUCTION}

Scoparia dulcis (Linn) is a plant grown in many parts of the world. It is found in India, Brazil, Africa, and other tropical region of the world. The plant had been reported to be of use by traditional healers for the treatment of a vast array of disease conditions like bronchitis, diabetes, hemorrhoids, hepatosis, hypertension, inflammation, and stomach troubles. It can also serve as analgesic, antibacterial, antifungal, anti-diarrhoeal, anti-inflammatory, antiherpetic, antipyretic, antiseptic, anti-spasmodic, antiviral, cytotoxic, emollient, emmenagogue, febrifuge, and hepatoprotective [1]-[6], neuroprotective and anticholinergic [7]. The use of the whole plant $\mathrm{S}$. dulcis for treatment of bite occasioned by the snake $B$. asper (Viperidae) in the province of Antioquia in Colombia has been reported [8]. The healers are said to administer the plant extracts to neutralize the toxins such as
Published Online: August 05,2021

ISSN: 2684-5199

DOI: $10.24018 /$ ejbio.2021.2.4.234

O. A. Adebiyi*

Department of Biochemistry, Ahmadu Bello University, Zaria, Nigeria.

(e-mail: olubodunadebiyi@gmail.com)

D. A. Ameh

Department of Biochemistry, Ahmadu

Bello University, Zaria, Nigeria.

(e-mail: danladiameh@yahoo.com)

E. Onyike

Department of Biochemistry, Ahmadu

Bello University, Zaria, Nigeria.

(e-mail: elewechi2003@yahoo.com)

D. B. James

Department of Biochemistry, Ahmadu Bello University, Zaria, Nigeria.

(e-mail: dbjams16187@yahoo.com)

*Corresponding Author phospholipase A2 present in the venom [9]. The plant is commonly known as Sweet broom weed and widely distributed in all the geopolitical zones of Nigeria. The plant had been listed as one of the Nigerian most patronized medicinal plants employed in the treatment of diabetes mellitus, cough, conjunctivitis, and gonorrhea [10]. Among the Hausa people of Nigeria, Scoparia dulcis (Linn) is usually administered by traditional birth attendants and old women to primigravids (women who just delivered a baby) as part of post natal care to help flush and clean the women post partum blood flow. It is also being used as love charm and often chewed to secure favour from people in authority [11]. Reference [12] reported the heamatinic, immuno-stimulatory and antibacterial potential of the plant. Several studies had been carried out on the anti- diabetic potential of the plant in animal models using streptozotocin or alloxan [13]-[19]. Bioactive components of Scoparia dulcis were found to 
include scoparic acid A, scoparic acid B [2], scopadulcic acid A and B, scopadulciol and scopadulin [1].

These studies support the claims of traditional use of the plant for the treatment of diabetes mellitus. However, in our literature survey no report was available on evaluation of this plant for its possible toxicity. The diseases treated using this herb can be classed into infectious or non-metabolic which require a short or medium term of treatment and metabolic diseases like diabetes mellitus which involve a long term (chronic) management. Therefore, we cannot talk of the safety of this plant without carrying out the chronic toxicity profiling of the plant. Hepatotoxicity is defined as injury to the liver or impairment of the liver function caused by exposure to xenobiotic such as drugs, food additives, alcohol, chlorinated solvents, peroxidized fatty acids, fungal toxins, radioactive isotopes, environmental toxicants, and even some medicinal plants [20]-[22]. Moreover, nephrotoxicity deals with damages done to the kidney by these substances. So, the present study was undertaken to evaluate possible toxicity of the ethanol leaf extract of Scoparia dulcis L to confirm its safety or otherwise on the liver and kidney in the management of chronic diseases which involve a long time of administration.

\section{MATERIALS AND METHODS}

\section{A. Plant Materials and Extraction}

The leaves of Scoparia dulcis was collected from Ahmadu Bello University Samaru campus, Zaria Nigeria and was authenticated at the Herbarium unit of Botany department of the University. The plant material was shade dried for two weeks and pulverized using a kitchen blender (Sonifer ${ }^{\circledR}$, model SF-8028). The powdered leaf sample was cold macerated using $70 \%$ ethanol for seventy two hours after which the solvent was evaporated using Rotary Vacuum Evaporator (Hahn Vapor, HS-2005V, Hahnshin Scientific Co., Korea) to obtain the Scoparia dulcis Ethanol leaf extract (SDELE) used for this study.

\section{B. Animals}

Healthy adult male albino rats weighing 110 to $130 \mathrm{~g}$ were obtained from National Animal Production and Research Institute (NAPRI, Vom, Nigeria) were grouped and housed in cages under 12 hours light dark cycle at $34 \pm 2{ }^{\circ} \mathrm{C}$ with free access to standard pellet diet and water ad libitum. The animals were allowed to acclimatize to the laboratory conditions for two weeks prior to the commencement of the experiment.

\section{Chemicals}

All chemicals and reagents used in this study are of analytical grade. Kits for estimation of biochemical parameters (Protein, Albumin, Creatinine, ALT, AST, and ALP) are product of RANDOX Laboratory Ltd. Ardmore United Kingdom.

\section{Acute Toxicity Study}

The toxicity test was carried out on albino rats (100-120 g) in accordance with the protocol devised by Reference [23]. On the first phase, animals were grouped into three of three rats per group and administered 10,100 and $1000 \mathrm{mg} / \mathrm{kg}$ body weight doses respectively of SDELE orally and monitored for twenty four hours for signs of toxicity like, tremor, restlessness, pyloerectile display, dizziness and death. In the second phase, another set of rats (one per group) were given oral dose of SDELE at 200, 400, 800 and $1600 \mathrm{mg} / \mathrm{kg}$ respectively and monitored for twenty four hours for signs of toxicity.

\section{E. Experimental Design Chronic Toxicity}

Albino rats were divided into four cages of five rats in each cage. They were placed on rat chow and allowed to drink water ad libitum. Group1 was administered distilled water as the control while the remaining groups were administered specified doses of SDELE orally once a day for a period of fourteen weeks.

The treatments were as follows:

- Group I: Normal rats were treated with $0.2 \mathrm{ml}$ distilled water.

- Group II: Normal rats treated with100 mg/kg body weight dose of SDELE.

- Group III: Normal rats treated with $200 \mathrm{mg} / \mathrm{kg}$ body weight dose of SDELE.

- Group IV: Normal rats treated with $400 \mathrm{mg} / \mathrm{kg}$ body weight dose of SDELE.

\section{F. Body Weight, Relative Organ Weight, Feed, and Fluid Intake}

The body weights of animals in each group were recorded on weekly basis while the water and feed intake were recorded on daily basis all through the period of the experiment. At the end of fourteen weeks of extract administration, the animals were weighed, sacrificed using light anaesthesia, bled appropriately and quickly dissected to harvest the liver, spleen, kidney, heart, and the lungs. These organs were rinsed in saline solution blotted dry and weighed.

\section{G. Haematological and Biochemical Analysis}

Blood was collected on after the fourteen week duration by cardiac puncture into EDTA container for hematological estimation using auto Hematology Analyzer (Mindray, BC2800) while blood for biochemical estimations were collected in plain specimen bottles and serum was obtained by centrifugation at $3000 \mathrm{rpm}$ for 10 minutes. Kits (RANDOX Laboratory Ltd. Ardmore United Kingdom) were used for biochemical assay while Serum electrolytes (Sodium and Potassium ions) were estimated using spectrophotometric technique [24].

\section{H. Histopathology}

The animals were dissected after a light anesthesia. The liver and kidney were harvested and fixed in $10 \%$ formol saline. The fixed tissues were transferred to a graded series of ethanol and then cleared in xylene. Once cleared, the tissues were infiltrated in molten paraffin wax in the oven at $58^{\circ} \mathrm{C}$. Serial section of 5 micrometers thick were obtained from a solid block of tissue, cleared, fixed in clean slides, stained with Haematoxylin and Eosin stains, and examined with the light microscope [25].

\section{Statistical Analysis}

Results were expressed as mean \pm SD. All data was subjected to one-way analysis of variance (ANOVA) and 
Tukey's post hoc test at $95 \%$ level of significance using MINITAB 17 statistical software.

\section{RESULT}

\section{A. Acute Toxicity Test}

The result of the acute toxicity test is shown in Table I. In the first phase of the experiment, there was mortality of one out of the three rats at $1000 \mathrm{mg} / \mathrm{kg}$ body weight dose. $200 \mathrm{mg} / \mathrm{kg}, 400 \mathrm{mg} / \mathrm{kg}, 800 \mathrm{mg} / \mathrm{kg}$, and $1600 \mathrm{mg} / \mathrm{kg}$ body weight doses were tried with mortality observed only at $1600 \mathrm{mg} / \mathrm{kg}$. The median lethal dose was estimated at $1100 \mathrm{mg} / \mathrm{kg}$ body weight.

\begin{tabular}{ccc}
\multicolumn{3}{c}{ TABLE I: ACUTE TOXICITY RESULT } \\
\hline Dose (mg/kg body & $\begin{array}{c}\text { Mortality } \\
\text { Index* }\end{array}$ & LD $_{50}$ \\
weight) & $0 / 3$ & \\
\hline Phase $1: 10$ & $0 / 3$ & \\
100 & $2 / 3$ & \\
1000 & $0 / 1$ & \\
Phase 2: 200 & $0 / 1$ & \\
400 & $0 / 1$ & $\sqrt{ } 800 \times 1600=1131$ \\
800 & $1 / 1$ & \\
1600 &
\end{tabular}

* Numberof deadanimalinthegroup

Totalnumberofanimalsinthegroup

\section{B. Effect of the Different Doses of SDELE on the Fluid and Feed Consumption in Normal Rats}

The feed and fluid intake pattern of rats in the chronic toxicity study of ethanol leaf extracts of S. dulcis (SDELE) in rats is shown in Fig. 1. There was no significant $(p>0.05)$ difference in the food intake $(\mathrm{g} / 100 \mathrm{~g}$ rat/day) in each of the treatment group when compared to the control. All the treatment groups exhibited the same pattern of food consumption. However, the groups treated with 100, 200 and $400 \mathrm{mg} / \mathrm{kg}$ body weight of SDELE elicited fluid intake propensity in a dose dependent manner.

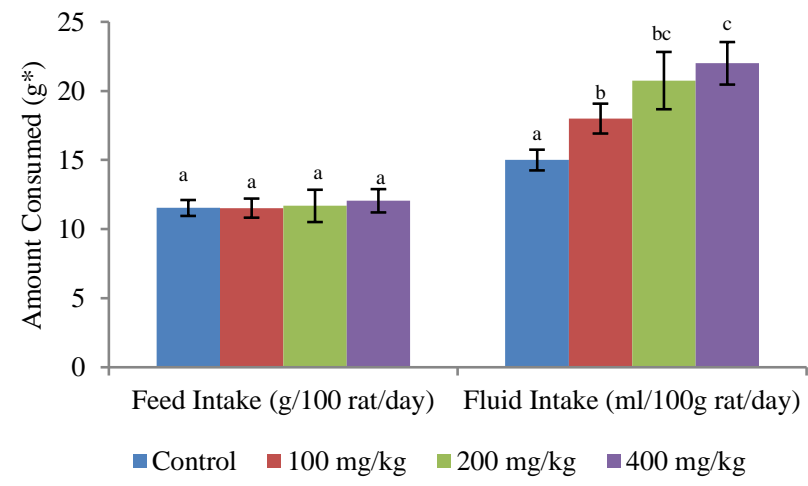

Fig.1. Effect of administration of SDELE on Feed and Fluid intake in normal rats for fourteen weeks.

${ }^{a-c}$ Values with different letter for a given parameter are significantly $(\mathrm{p}<0.05)$ different from the other group. ${ }^{*}$ Density of water is $1 \mathrm{~g} / \mathrm{m}$.

\section{Effect of the Different Doses on Body and Relative Organ Weight upon Chronic Administration}

The change in weight of rat administered $100 \mathrm{mg} / \mathrm{kg}$, $200 \mathrm{mg} / \mathrm{kg}$ and $400 \mathrm{mg} / \mathrm{kg}$ of SDELE is shown in Fig. 2. The group administered $400 \mathrm{mg} / \mathrm{kg}$ body weight of SDELE shows a significant $(p<0.05)$ reduction in mean weight when compared with the control and other groups as from the eleventh week while significant $(\mathrm{p}<0.05)$ reduction in mean weight was noticed in the group treated with $200 \mathrm{mg} / \mathrm{kg}$ body weight dose at the thirteenth week. However, the $100 \mathrm{mg} / \mathrm{kg}$ dose of the leaf and stem extract of $S$. dulcis showed a similar trend in weight gained as the control group. Furthermore, there was a significant $(\mathrm{p}<0.05)$ increase in the relative organ weight of the liver and heart tissues in the rat group administered $400 \mathrm{mg} / \mathrm{kg}$ body weight dose of SDELE (Table II) while there was no effect of the chronic administration of the extract on the relative organ weight of the spleen, kidney and lungs at $100 \mathrm{mg} / \mathrm{kg}, 200 \mathrm{mg} / \mathrm{kg}$, and $400 \mathrm{mg} / \mathrm{kg}$ of SDELE.

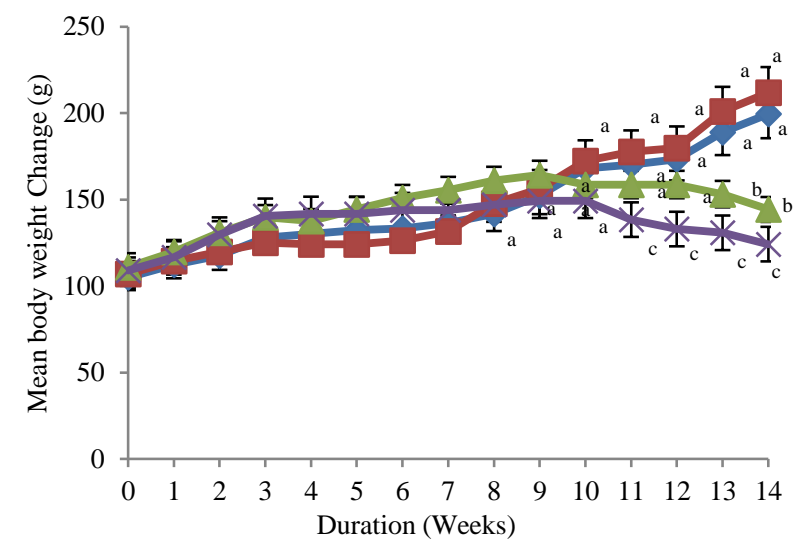

Fig.2. Effect of administration of SDELE on mean weight change of rats for fourteen weeks.

${ }^{a-c}$ Values with different letters near the lines for a given week are significantly $(\mathrm{p}<0.05)$ different from each other group of animal.

\section{Effect of SDELE on Haematological Parameter upon Chronic Administration in Rats}

The leaf extract of $S$. dulcis elicited significant $(\mathrm{p}<0.05)$ increase in the percentage of the lymphocytes in rat groups administered 200 and $400 \mathrm{mg} / \mathrm{kg}$ body weight doses of the extracts (Table III). There was no significant $(p>0.05)$ difference in every other haematological parameter of the rat groups treated with the different doses of the extract.

\section{E. Effect of Different Doses of SDELE on Liver Function upon Chronic Administration}

The extract SDELE at $400 \mathrm{mg} / \mathrm{kg}$ body weight dose caused a significant $(\mathrm{p}<0.05)$ increase in the concentration of total protein, the serum level of albumin, A/G, bilirubin (total and direct), alkaline phosphatase, alanine amino transferases, and aspartate amino transferases when compared with the control group after fourteen weeks of administration (Table IV).

\section{F. Effect of the Different Doses on Kidney Function upon Chronic Administration}

The Ethanol leaf extract of Scoparia dulcis (Linn) caused a very significant $(\mathrm{p}<0.05)$ increase in the blood urea, creatinine and potassium levels at $200 \mathrm{mg} / \mathrm{kg}$ and $400 \mathrm{mg} / \mathrm{kg}$ body weight while the extract also caused a significant $(\mathrm{p}<0.05)$ reduction in serum concentration of sodium at these dosage levels. The extract however did not show any effect different with the control group upon administration at $100 \mathrm{mg} / \mathrm{kg}$ dose level (Table IV). 
TABLE II: EFFECT OF ETHANOL LEAF AND STEM EXTRACT OF S. DULCIS ON RELATIVE ORGAN WEIGHT IN THE Chronic TOXICITY STUDY IN RATS

\begin{tabular}{cccccc}
\hline Treatment & Spleen & Liver & $\begin{array}{c}\text { Kidneys } \\
(\mathrm{g} / 100 \mathrm{~g})\end{array}$ & Lung & Heart \\
\hline Normal Control & $0.30 \pm 0.05^{\mathrm{a}}$ & $3.36 \pm 0.30^{\mathrm{a}}$ & $0.43 \pm 0.05^{\mathrm{a}}$ & $0.79 \pm 0.17^{\mathrm{a}}$ & $0.42 \pm 0.05^{\mathrm{a}}$ \\
Normal Rat+SDELE $(100 \mathrm{mg} / \mathrm{kg})$ & $0.31 \pm 0.06^{\mathrm{a}}$ & $3.45 \pm 0.27^{\mathrm{a}}$ & $0.42 \pm 0.05^{\mathrm{a}}$ & $0.83 \pm 0.25^{\mathrm{a}}$ & $0.40 \pm 0.04^{\mathrm{a}}$ \\
Normal Rat+SDELE $(200 \mathrm{mg} / \mathrm{kg})$ & $0.33 \pm 0.04^{\mathrm{a}}$ & $3.79 \pm 0.38^{\mathrm{ab}}$ & $0.42 \pm 0.05^{\mathrm{a}}$ & $0.99 \pm 0.16^{\mathrm{a}}$ & $0.42 \pm 0.04^{\mathrm{a}}$ \\
Normal Rat+SDELE $(400 \mathrm{mg} / \mathrm{kg})$ & $0.37 \pm 0.07^{\mathrm{a}}$ & $3.98 \pm 0.26^{\mathrm{b}}$ & $0.39 \pm 0.06^{\mathrm{a}}$ & $0.81 \pm 0.16^{\mathrm{a}}$ & $0.52 \pm 0.03^{\mathrm{b}}$ \\
\hline
\end{tabular}

${ }^{a-b}$ Values expressed as Mean \pm SD of five animals with different letters along a column are significantly $(\mathrm{p}<0.05)$ different from each other group of animals. SDELE means $S$. dulcis ethanol leaf extract.

TABLE III: EFFECT OF ETHANOL LEAF EXTRACT OF S. DULCIS ON HAEMATOLOGICAL PARAMETERS IN THE CHRONIC TOXICITY STUDY IN RATS

\begin{tabular}{|c|c|c|c|c|}
\hline Parameters & Normal Control & $\begin{array}{c}\text { Normal Rats } \\
+ \text { Extract }(100 \mathrm{mg} / \mathrm{kg})\end{array}$ & $\begin{array}{c}\text { Normal Rats } \\
+ \text { Extract }(200 \mathrm{mg} / \mathrm{kg})\end{array}$ & $\begin{array}{c}\text { Normal Rats } \\
+ \text { Extract }(400 \mathrm{mg} / \mathrm{kg})\end{array}$ \\
\hline Red blood cell $\left(\times 10^{6} / \mu \mathrm{l}\right)$ & $4.87 \pm 0.25^{\mathrm{a}}$ & $4.97 \pm 0.25^{\mathrm{a}}$ & $4.90 \pm 0.44^{\mathrm{a}}$ & $5.00 \pm 0.51^{\mathrm{a}}$ \\
\hline Haemoglobin $(\mathrm{g} / \mathrm{dl})$ & $13.50 \pm 3.44^{\mathrm{a}}$ & $13.37 \pm 2.87^{\mathrm{a}}$ & $13.83 \pm 1.37^{\mathrm{a}}$ & $15.72 \pm 1.56^{\mathrm{a}}$ \\
\hline Haematocrit (\%) & $40.91 \pm 5.26^{\mathrm{a}}$ & $40.33 \pm 7.62^{\mathrm{a}}$ & $41.88 \pm 6.04^{\mathrm{a}}$ & $47.64 \pm 4.62^{\mathrm{a}}$ \\
\hline Mean Corpuscular Volume (fl) & $8.4 \pm 0.46^{\mathrm{a}}$ & $8.11 \pm 0.42^{\mathrm{a}}$ & $8.55 \pm 0.44^{\mathrm{a}}$ & $9.50 \pm 0.51^{\mathrm{a}}$ \\
\hline Mean Corpuscular Haemoglobin (pg) & $27.72 \pm 6.08^{\mathrm{a}}$ & $26.90 \pm 2.76^{\mathrm{a}}$ & $28.22 \pm 6.43^{\mathrm{a}}$ & $31.44 \pm 8.69^{\mathrm{a}}$ \\
\hline $\begin{array}{l}\text { Mean Corpuscular Haemoglobin } \\
\text { Concentration }(\mathrm{g} / \mathrm{dl})\end{array}$ & $33.00 \pm 0.00^{\mathrm{a}}$ & $33.07 \pm 0.11^{\mathrm{a}}$ & $33.02 \pm 0.00^{\mathrm{a}}$ & $33.00 \pm 0.00^{\mathrm{a}}$ \\
\hline Platelet $\left(\times 10^{5} / \mu \mathrm{l}\right)$ & $139.33 \pm 48.06^{\mathrm{a}}$ & $144.67 \pm 17.47^{\mathrm{a}}$ & $170.00 \pm 17.32^{\mathrm{a}}$ & $182.00 \pm 3.46^{\mathrm{a}}$ \\
\hline White blood cell $\left(\times 10^{3} / \mu \mathrm{l}\right)$ & $3.13 \pm 1.55^{\mathrm{a}}$ & $6.33 \pm 2.31^{\mathrm{a}}$ & $6.17 \pm 1.76^{\mathrm{a}}$ & $4.13 \pm 3.51^{\mathrm{a}}$ \\
\hline Neutrophil (\%) & $54.65 \pm 0.58^{\mathrm{a}}$ & $54.33 \pm 3.06^{\mathrm{a}}$ & $53.34 \pm 3.57^{\mathrm{a}}$ & $52.33 \pm 2.83^{\mathrm{a}}$ \\
\hline Lymphocyte (\%) & $42.63 \pm 0.57^{\mathrm{a}}$ & $42.67 \pm 1.05^{\mathrm{a}}$ & $45.32 \pm 0.58^{\mathrm{b}}$ & $46.00 \pm 1.00^{\mathrm{b}}$ \\
\hline Monocytes (\%) & $1.67 \pm 0.58^{\mathrm{a}}$ & $1.63 \pm 0.62^{\mathrm{a}}$ & $1.33 \pm 0.29^{\mathrm{a}}$ & $1.00 \pm 0.10^{\mathrm{a}}$ \\
\hline Eosinophil (\%) & $1.00 \pm 0.10^{\mathrm{a}}$ & $1.33 \pm 0.23^{\mathrm{a}}$ & $1.00 \pm 0.10^{\mathrm{a}}$ & $0.67 \pm 0.58^{\mathrm{a}}$ \\
\hline Basophil (\%) & $0.00 \pm 0.00^{\mathrm{a}}$ & $0.00 \pm 0.00^{\mathrm{a}}$ & $0.00 \pm 0.00^{\mathrm{a}}$ & $0.00 \pm 0.00^{\mathrm{a}}$ \\
\hline
\end{tabular}

${ }^{\text {a-b }}$ Values expressed as Mean \pm SD of five animals. Values with different letters along a row are significantly $(\mathrm{p}<0.05)$ different from each other.

TABLE IV: EFFECT OF ETHANOL LEAF EXTRACT OF S. DULCIS ON BLOOD BIOCHEMICAL PARAMETERS IN THE CHRONIC TOXICITY STUDY IN RATS

\begin{tabular}{|c|c|c|c|c|}
\hline Parameter & Normal Control & $\begin{array}{c}\text { Normal Rats } \\
+ \text { Extract }(100 \mathrm{mg} / \mathrm{kg})\end{array}$ & $\begin{array}{c}\text { Normal Rats } \\
+ \text { Extract }(200 \mathrm{mg} / \mathrm{kg}) \\
\end{array}$ & $\begin{array}{c}\text { Normal Rats } \\
+ \text { Extract }(400 \mathrm{mg} / \mathrm{kg})\end{array}$ \\
\hline Total Protein $(\mathrm{g} / \mathrm{L})$ & $65.33 \pm 3.44^{\mathrm{a}}$ & $65.75 \pm 4.93^{\mathrm{a}}$ & $68.33 \pm 4.31^{\mathrm{a}}$ & $74.93 \pm 5.62^{b}$ \\
\hline Albumin $(\mathrm{g} / \mathrm{L})$ & $36.99 \pm 3.11^{\mathrm{a}}$ & $37.39 \pm 2.36^{\mathrm{a}}$ & $38.92 \pm 1.07^{\mathrm{a}}$ & $44.92 \pm 3.50^{b}$ \\
\hline Albumin/Globulin & $1.31 \pm 0.12^{\mathrm{a}}$ & $1.34 \pm 0.18^{\mathrm{a}}$ & $1.34 \pm 0.13^{\mathrm{ab}}$ & $1.50 \pm 0.06^{\mathrm{b}}$ \\
\hline Total Bilirubin (mmol/L) & $2.74 \pm 0.27^{\mathrm{a}}$ & $2.87 \pm 0.70^{\mathrm{a}}$ & $3.07 \pm 0.60^{\mathrm{a}}$ & $4.61 \pm 0.70^{\mathrm{b}}$ \\
\hline Direct Bilirubin (mmol/L) & $1.35 \pm 0.11^{\mathrm{a}}$ & $1.37 \pm 0.04^{\mathrm{a}}$ & $1.51 \pm 0.29^{\mathrm{a}}$ & $2.44 \pm 0.45^{\mathrm{b}}$ \\
\hline Urea $(\mathrm{mmol} / \mathrm{L})$ & $5.91 \pm 0.13^{\mathrm{a}}$ & $6.24 \pm 0.64^{\mathrm{a}}$ & $10.05 \pm 0.78^{b}$ & $10.35 \pm 0.96^{\mathrm{b}}$ \\
\hline Creatinine $(\mathrm{mmol} / \mathrm{L})$ & $51.56 \pm 2.34^{\mathrm{a}}$ & $50.40 \pm 1.81^{\mathrm{a}}$ & $57.88 \pm 5.72^{\mathrm{ab}}$ & $61.42 \pm 5.53^{b}$ \\
\hline Alkaline Phosphatase (U/L) & $61.28 \pm 3.92^{\mathrm{a}}$ & $66.78 \pm 6.09^{\mathrm{ab}}$ & $79.78 \pm 11.75^{\mathrm{b}}$ & $118.28 \pm 14.91^{\mathrm{c}}$ \\
\hline Alanine aminotransferase(U/l) & $33.40 \pm 6.40^{\mathrm{a}}$ & $35.71 \pm 3.86^{\mathrm{a}}$ & $48.67 \pm 6.47^{\mathrm{b}}$ & $61.45 \pm 6.55^{\mathrm{b}}$ \\
\hline Aspartate aminotransferase(U/l) & $80.22 \pm 2.49^{\mathrm{a}}$ & $79.40 \pm 3.98^{\mathrm{a}}$ & $88.88 \pm 3.12^{\mathrm{b}}$ & $92.40 \pm 3.62^{\mathrm{b}}$ \\
\hline Sodium Ion (mmol/L) & $140.20 \pm 3.19^{\mathrm{a}}$ & $139.00 \pm 2.49^{\mathrm{a}}$ & $139.80 \pm 1.92^{\mathrm{a}}$ & $131.80 \pm 6.30^{\mathrm{b}}$ \\
\hline Potassium Ion (mmol/L) & $4.02 \pm 0.31^{\mathrm{a}}$ & $4.06 \pm 0.32^{\mathrm{a}}$ & $4.58 \pm 0.16^{\mathrm{b}}$ & $5.30 \pm 0.37^{\mathrm{c}}$ \\
\hline
\end{tabular}

${ }^{\mathrm{a}-\mathrm{d}}$ Values expressed as Mean \pm SD of five animals. Values with different letters along a row are significantly (p<0.05) different from each other.

\section{G. Effect of Different Doses of SDELE on Histo- Architecture of the Liver and Kidney}

Liver and kidney of rat treated with $100 \mathrm{mg} / \mathrm{kg}$ body weight dose of extract showed no remarkable pathology when compared to the liver from the control group. However, the liver from the group of rats administered $200 \mathrm{mg} / \mathrm{kg}$ body weight dose of extract for fourteen weeks showed mild haemorrhage (Plate 1c) while the liver architecture from the $400 \mathrm{mg} / \mathrm{kg}$ body weight dose group showed a vast area of haemorrhage (Plate 1d). Moreover, the kidney of rat administered $200 \mathrm{mg} / \mathrm{kg}$ body weight dose of extract showed areas of haemorrhage and vascular congestion (Plate 2c) while the architecture of kidney of rat administered $400 \mathrm{mg} / \mathrm{kg}$ body weight dose for a period of fourteen weeks revealed haemorrhage and renal damage (Plate $2 \mathrm{~d}$ ).

\section{DISCUSSION}

Medicinal plants are very good sources of remedy for treating a vast array of disease conditions. However, studies had proved the potential danger of toxicity of these plants' extract on the organs in experimental animals [26]-[28]. The toxicity may arise from inappropriate use (usually an overdose), inappropriate identification of the plant material, or be related to the presence of specific hepatotoxic and nephrotoxic compounds in the plant material.

The animal groups administered the extracts manifested more food consumption but same pattern of water consumption when compared with the control. The significant $(\mathrm{p}<0.05)$ increase in the food consumption pattern of the treated groups may signify the appetite stimulatory potential of these extracts. Some appetite stimulatory plant extracts had been documented in the literature [29]-[31]. Food is known to supply nutrients needed for energy, growth, and maintenance of the entire body system. The more the quantity of the nutrients through food supplies, the more health, activity, and body mass of the subjects under a normal physiological condition. However, weight gain decreases were significantly $(\mathrm{p}<0.05)$ noticeable as from the eleventh week at 200 and $400 \mathrm{mg} / \mathrm{kg}$ of SDELE administration. The reduction in weight gained of the groups administered higher doses of extract despite the high food consumption rate is an indication that food could no longer be converted for growth appropriately as from the eleventh week for SDELE. This could be adduced to the possibility of toxicity of the dosage of the extract at these periods which might have led to damages to internal tissues and organs and thus need to go through healing cycle. The nutrients that might have been employed in building body mass would have to be employed 
in replacement of the affected cells. It could therefore be inferred that administration of the leaf extract of $S$. dulcis at 200 and $400 \mathrm{mg} / \mathrm{kg}$ body weight may be safe until the eleventh week. Generally, the leaf and stem extract of these study plants are safe at 200 and $400 \mathrm{mg} / \mathrm{kg}$ body weight administration on sub-chronic level.

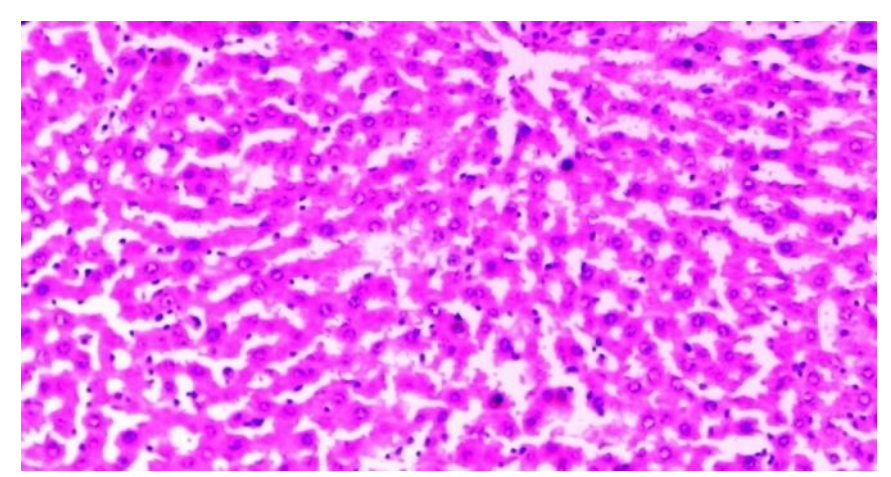
Plate 1a. Normal liver architecture (H \& E. ×100).

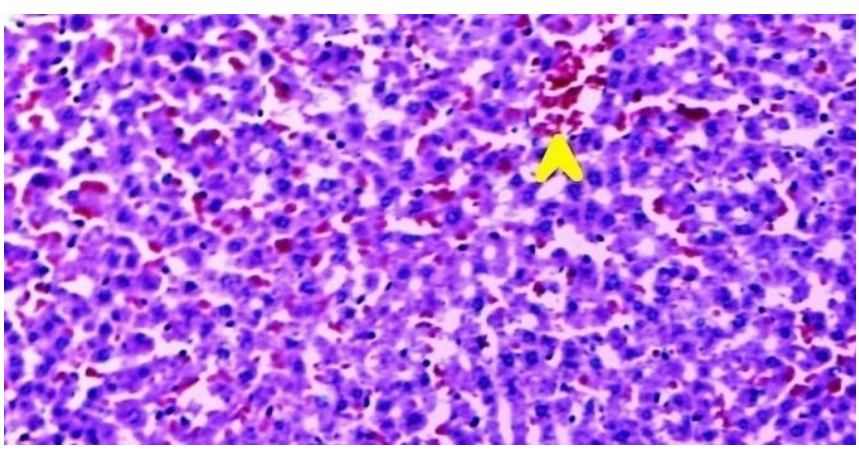

Plate1 c. Liver, $200 \mathrm{mg} / \mathrm{kg}(\mathrm{H} \&$ E. $\times 100)$.

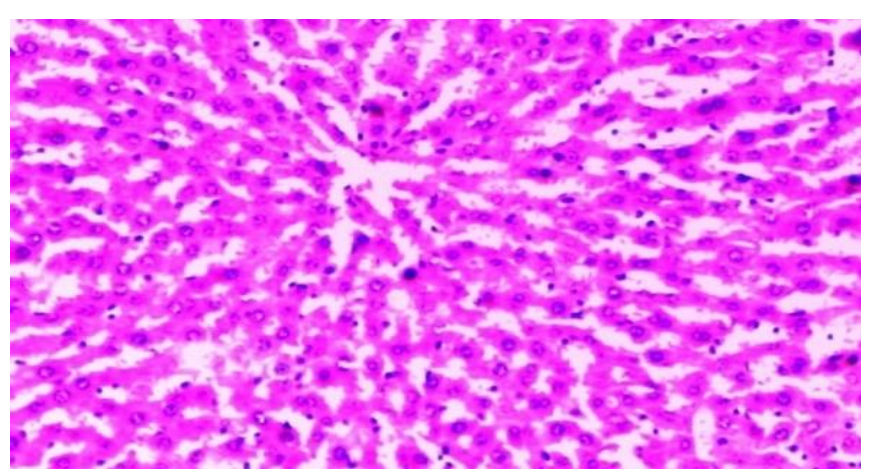

Plate1b. Liver, 100 mg/kg (H \& E. ×100).

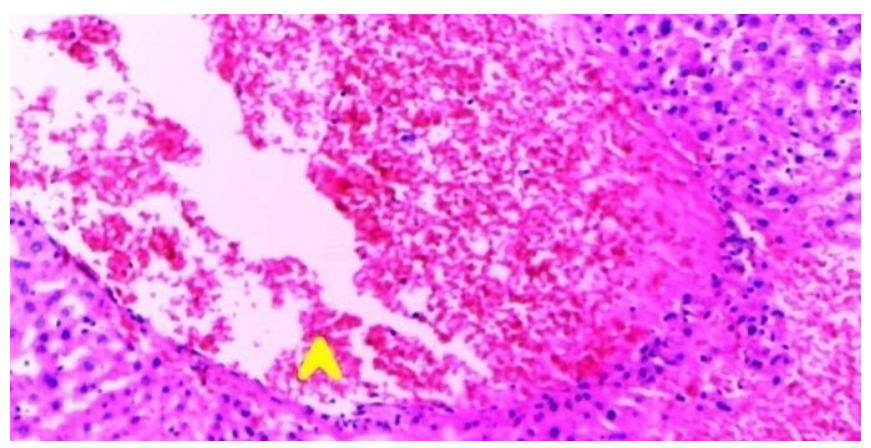

Plate1d. Liver, $400 \mathrm{mg} / \mathrm{kg}(\mathrm{H} \&$ E. $\times 100)$.

Plates 1a-d: Photomicrographs of: (a) the liver of a normal control rat; (b) liver of rats administered $100 \mathrm{mg} / \mathrm{kg}$ dose of Scoparia dulcis ethanol leaf extract showing intact tissue;(c) liver of rat administered $200 \mathrm{mg} / \mathrm{kg}$ dose of Scoparia dulcis showing areas of mild haemorrhage (arrowed); (d) rat liver administered $400 \mathrm{mg} / \mathrm{kg}$ Scoparia dulcis leaf extract showing vast area of haemorrhage (arrowed) (H \&E. $\times 100)$.

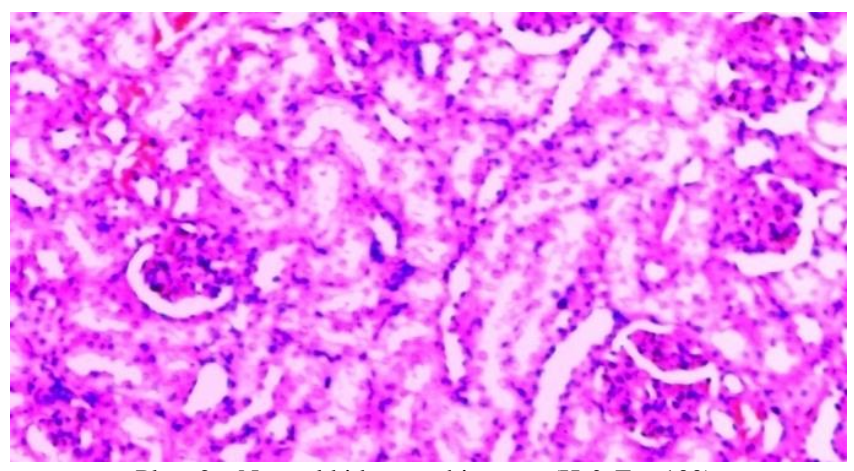

Plate 2a. Normal kidney architecture (H \& E. $\times 100)$.

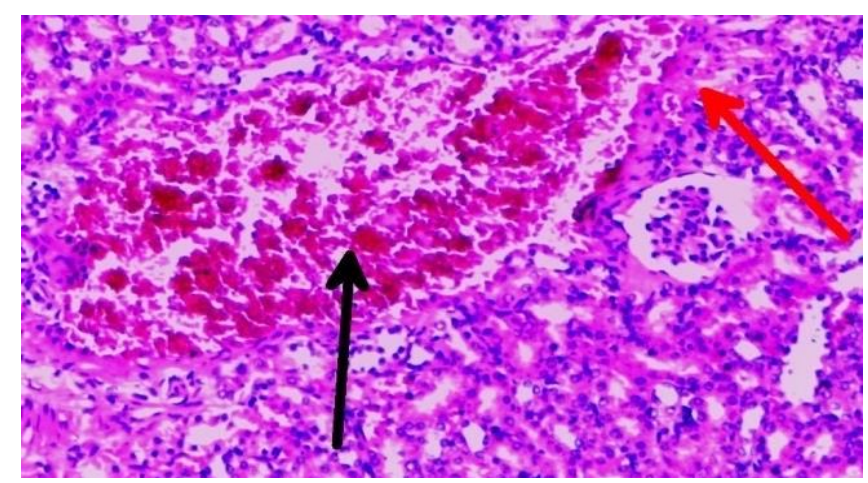

Plate2 c. Kidney, 200 mg/kg (H \& E. × 100).

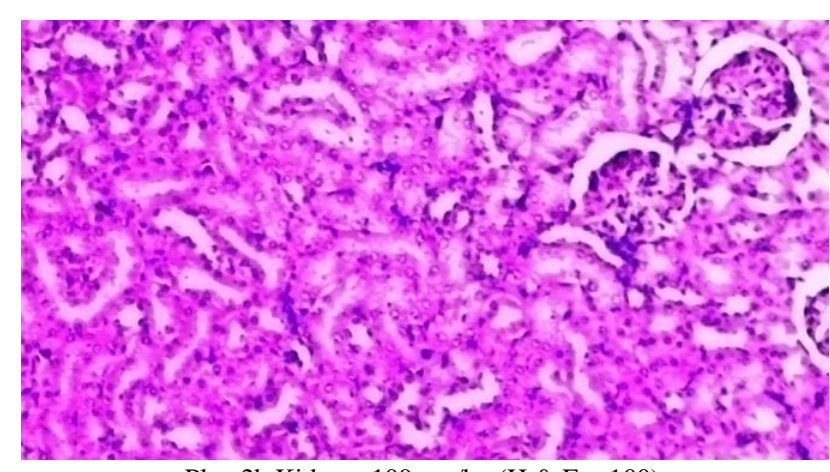

Plate2b.Kidney, 100 mg/kg (H \& E. ×100).

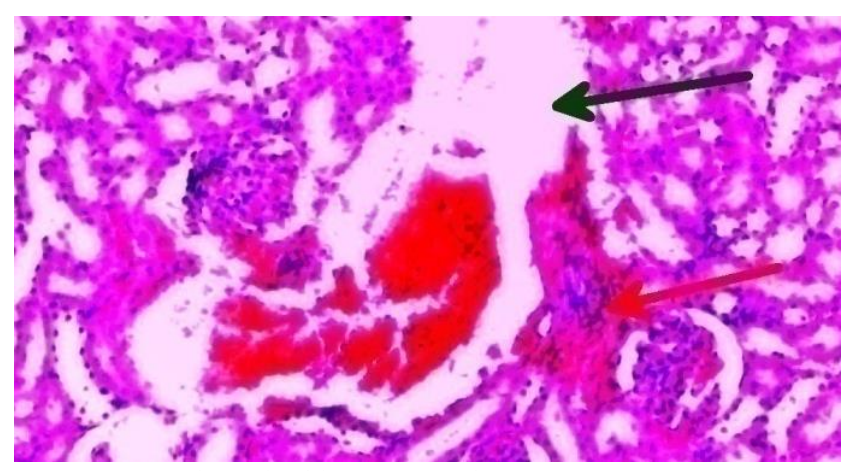

Plate2 d. Kidney, 400 mg/kg (H \& E. ×100).

Plate 2a-d. Photomicrographs of: (a) the kidney of a normal control rat showing unremarkable kidney with the cortex containing glumeruli and medullar renal tubules; (b) the kidney of rat administered $100 \mathrm{mg} / \mathrm{kg}$ leaf extract of Scoparia dulcis showing intact tissue; (c)the kidney of rat administered $200 \mathrm{mg} / \mathrm{kg}$ leaf extract of Scoparia dulcis showing areas of haemorhage (arrowed) and vascular congestion (arrowed); (d) the kidney of rat administered $400 \mathrm{mg} / \mathrm{kg}$ leaf extract of Scoparia dulcis showing areas of haemorhage and renal damage (arrowed). 
The significant $(\mathrm{p}<0.05)$ increase in the relative weight (hypertrophy) of the liver and heart in the group administered $400 \mathrm{mg} / \mathrm{kg}$ body weight dosage of $S$. dulcis ethanol suggests the possibility of toxicity of these extracts at $400 \mathrm{mg} / \mathrm{kg}$ body weight dose. Hypertrophy may be good if it is physiological, when characterized by normal cellular growth (increase in cell size but not cell number) and enhanced function. Hypertrophy is caused by hormonal stimulation, inflammation and overload of the organ concerned as some cases when there is increased quantity of blood in the capillaries of, and retarded circulation in the affected organ.

Assessment of haematological parameters can be used to determine haematopoietic and haematinic related functions of an extract or compound. They can also be used to determine the extent of deleterious effect foreign compounds including plant extracts can exert on the blood constituents of an animal [32]. Such toxicity testing is relevant to risk evaluation as changes in the haematological system had been reported to have higher predictive value for human toxicity when data are translated from animal studies [33]. It can also be used to explain blood relating functions of chemical compound or plant extracts. The differential white blood counts revealed significant $(\mathrm{p}<0.05)$ increase in the level of lymphocytes by animal groups administered 200 and $400 \mathrm{mg} / \mathrm{kg}$ body weight doses of SDELE. The lymphocyte is the main effector cell of the immune system [34]. The observed dose dependent increase in this parameter may likely be an indication that SDELE may exert serious challenge on the immune system of the treated animals at the 200 and $400 \mathrm{mg} / \mathrm{kg}$ body weight dose levels. The $100 \mathrm{mg} / \mathrm{kg}$ dose of this extract (SDELE) did not pose challenge on the immune apparatus of the animals as indicated by the non- significant $(p>0.05)$ difference in the level of their lymphocytes when compared with the control group.

The liver and kidney are two major organs in the mammalian body central to many metabolic transformations taking place in the body. The liver is saddled with the functions of detoxification, excretion of bile, storage of glycogen and vitamins, manufacture of protein (fibrinogen, albumin, and globulin), synthesis of blood clotting factors (fibrinogen, prothrombin, factor V, VII, IX, X and XI), synthesis of cholesterol, phospholipid, endogenous triglycerides, and lipoproteins (lipid metabolism) and removal of worn-out cells and microorganism through phagocytocis by the Kupfer cells [35], [36]. Where and when there is an attack or damage to this robust organ, there is tendency of compromise of one or more of these functions thereby leading to derangement of metabolic processes with devastating effect on the whole system which could culminate in complications and eventually death. Administration of SDELE at $200 \mathrm{mg} / \mathrm{kg}$ and $400 \mathrm{mg} / \mathrm{kg}$ body weight doses for fourteen weeks causes a tremendous increase in the serum level of bilirubin, ALP, ALT, and albumin. Bilirubin is mainly formed from the breakdown of heamoglobin in the cells of the liver, spleen, and bone marrow. The heame is removed and the porphyrin of the globin part is converted to biliverdin which is reduced to bilirubin. The bilirubin is attached to albumin making it insoluble and cannot be excreted by the kidney. It is found in this form and referred to as unconjugated bilirubin. Glucuronic acid in the liver could conjugate with bilirubin however making it soluble and excretable by the kidney (conjugated bilirubin). In situation of diminished function of the liver cells as in damage, conjugated bilirubin became accumulated and found in the blood in high concentration as we have in this study. Hence the extract could have caused damage to the liver at 200 and $400 \mathrm{mg} / \mathrm{kg}$ body weight dose level as seen in high concentration of bilirubin in the concerned groups. Hyperproteinemia observed in the serum of the group is an indication of chronic liver disease and nephrotic syndrome [37]. This may be a pointer that the extract is not friendly to the liver at $400 \mathrm{mg} / \mathrm{kg}$ body weight dose. ALP, AST, and ALT concentration are often used as biomarkers of hepatic damage [38]. In the present study we found a significantly higher activities of these enzymes in the serum of rats administered 200 and $400 \mathrm{mg} / \mathrm{kg}$ dose levels of SDELE. This is also an indication of possible damage to liver by this extract at these doses.

The kidney is the major organ responsible for excretion of toxins and their metabolites, maintenance of blood $\mathrm{pH}$, water and electrolyte balance in the body, filtration, production of erythropoietin, reabsorption, and concentration of urine [39]. The role of the kidney as the primary eliminator of exogenous drugs and toxins, in addition to the fact that it is characterized by a large volume of blood supply which ensures a high level of toxicant delivery over a period of time, predisposes this important organ to nephrotoxicity and enhances its vulnerability to developing various forms of injury [40], [41]. The serum levels of urea, uric acid and creatinine are often used as markers for kidney function [42], [43]. The highly significant increase $(\mathrm{p}<0.05)$ noticed in this study in the concentration of serum urea, uric acid, potassium ion and creatinine in the group administered $200 \mathrm{mg} / \mathrm{kg}$ and $400 \mathrm{mg} / \mathrm{kg}$ body weight doses is noteworthy. The increased level of these biomarkers is a pointer to the nephrotoxicity potential of the extract at 200 and $400 \mathrm{mg} / \mathrm{kg}$ dose levels. This result corroborates the work of References [44] and [45] who reported toxic diterpene and ingenane esters from known medicinal plants. Also, Alstonia boonei, one of the 10 most commonly used folkloric medicinal plants in southwest Nigeria as reported [46] in spite of the numerous benefits, has been shown to be capable of causing nephrotoxicity upon its chronic consumption [47], [48]. It can therefore be explained that possibility of toxicity could not be completely ruled out in a plant as a result of having some therapeutic properties which form the basis for safe dosage level.

The histopathological examination confirmed the different levels of damage suffered by the liver and kidneys of rats administered $200 \mathrm{mg} / \mathrm{kg}$ and $400 \mathrm{mg} / \mathrm{kg}$ dose levels of SDELE for a period of fourteen weeks. At the lower dose, there was a mild haemorrhage which proceeded to affect a large portion of the liver at $400 \mathrm{mg} / \mathrm{kg}$ body weight dose. Basically, when heamorrhage occurs on a robust tissue like the liver, the tissue responds in a reactive or a reparative process to form fibrosis with concomitant change in the morphology and function of such tissue. The histoarchitecture of the kidney also revealed haemorrhage and vascular congestion at $200 \mathrm{mg} / \mathrm{kg}$ dose and renal damage at $400 \mathrm{mg} / \mathrm{kg}$ body weight dose respectively, confirming the toxicity of SDELE at these dose levels to the organ at chronic administration. However, the liver and kidney were not affected by the extract at $100 \mathrm{mg} / \mathrm{kg}$ body weight dose upon 
chronic administration indicating the safety of the extract to these two organs at that concentration.

\section{CONCLUSION}

This research documents and scientifically elucidated the safety profiling of Scoparia dulcis ethanol leaf extract: a plant widely used as an anti-diabetic, immune stimulatory, aphrodisiac and blood cleansing/tonic agent. It is thus a good candidate for further research efforts as it shows tendencies of damaging the liver and the kidney on prolong usage. Herbal medicine is gaining more ground because of economic hardship especially in the third world countries and the belief of absence of side effects. However, this study which is first of its kind on Scoparia dulcis is an eye opener on the serious need to carry out comprehensive toxicity studies of all our medicinal herbs to strike a balance between cure and safety. Ethanol leaf extract of Scoparia dulcis has shown hepatotoxic and nephrotoxic tendencies at dose as low as $200 \mathrm{mg} / \mathrm{kg}$ body weight at chronic administration though it is very safe at $100 \mathrm{mg} / \mathrm{kg}$ body weight dose.

\section{REFERENCES}

[1] T, K. Hayashi, Y. Miwa, T. Taga, N. Morita, Antiviral agents of plant origin III. Scopadulin, a novel tetracyclic diterpene from Scoparia dulcis L. Chemical and Pharmaceutical Bulletin; 38, 1990: 945-947.

[2] T. Hayashi., K. Okamura., Y. Tamada., A. Iida., T. Fujita., N. Morita, A new chemotype of Scoparia dulcis. Phytochemical Analysis, 33, 1993: 349-352.

[3] M. Ahmed, H.A. Shikha, S.K. Sadhu, M.T. Rahman, B.K. Datta. Analgesic, diuretic, and anti-inflammatory principle from Scoparia dulcis. Pharmazie; 2001, 56(8):657-60.

[4] J. Yisa, Phytochemical analysis and Antimicrobial activity of Scoparia dulcis and Nymphaea lotus. Australian Journal of Basic and Applied Sciences. Vol. 3(4), 2009: 3975-3979.

[5] J.C. Tsai, W.H. Peng, T.H. Chiu, S.C. Huang, T.H. Huang, Z.R. Lai, Hepatoprotective effect of Scoparia dulcis on carbon tetrachloride induced acute liver injury in mice. American Journal of Chinese Medicine; 3, 2010:761-775.

[6] A.I. Alli, J.O. Ehinmidu, and Y.K.E. Ibrahim, Preliminary Phytochemical Screening and Antimicrobial Activities of Some Medicinal Plants Used in Ebiraland. Bayero Journal of Pure and Applied Sciences, 2011, 4(1): 10 - 16.

[7] J.B. Harborne, Phytochemical methods guide to modern Technique of Plant analysis. Edn 3, Chapman and Hall, London, 1998.

[8] M. Kpodar, S. Lawson-Evi, P. Bakoma. et al., "Ethnopharmacological survey of plants used in the treatment of diabetes mellitus in south of Togo (Maritime Region)," Journal of Herbal Medicine, 2015, vol. 5, no. 3 , pp. $147-152$.

[9] J. Vasquez, S.L. Jim'enez., I.C. G'omezet al., "Snakebites and ethnobotany in the Eastern region of Antioquia, Colombia-the traditional use of plants," Journal of Ethnopharmacology, 2013, vol.146, no. 2, pp. 449-455.

[10] M.O. Soladoye and O.O Oyesiku, "Taxonomy of Nigerian Medicinal Plants" in A Textbook of Medicinal Plants from Nigeria, T. Odubgemi, Ed., Akoka-Yaba Lagos: Lagos University Press, 2008, ch 11, pp 93149.

[11] S.E. Okhale, M.O. Amanabo, I.A. Jegede, H.O. Egharevba, I.W. Muazzam, O.F. Kunle, Phytochemical and Pharmacognostic Investigation of Antidiabetic Scoparia dulcis Linn Scrophulariaceae Whole Plant Grown in Nigeria. Researcher, 2010, 2 (16); 7-16.

[12] A.I. Alli, J.O. Ehinmidu, and E.O. Igbadi, Evaluation of Antibacterial Properties, Acute Toxicity and Immuno-stimulatory Potential of Scoparia dulcis. Nigerian Journal of Biotechnology, 2013, Vol. 26: 2125.

[13] M.R. Mishra, A. Mishra, D.K. Pradhan, R.K. Behera, S. Jha, and A.K. Panda, Phytochemical screening of Scoparia dulcis L. (Scrophulariaceae) International Research Journal of Pharmaceutical Science, 2013, 4(1); 9-13.
[14] M. Latha, L. Pari, Modulatory effect of Scoparia dulcis in oxidative stress induced lipid peroxidation in streptozotocin diabetic rats. Journal of Medicinal Food,2003, 6, 379-386.

[15] M. Latha, L Pari, (2004). Efficacy of aqueous extract of Scoparia dulcis on blood glucose, plasma insulin and polyol pathway in experimental diabetes. Brazilian Journal of Medical and Biological Research, 2004, $37,577-586$.

[16] M. Latha L. Pari, S. Sitasawad, R. Bhonde, Insulin-secretagogue activity and cytoprotective role of the traditional antidiabetic plant Scoparia dulcis (Sweet Broom weed). Life Science, 2004, 75:20032014.

[17] M. Latha, L. Pari, S. Sandhya, R. Bhonde. Scoparia dulcis, a traditional antidiabetic plant, protects against streptozotocin induced oxidative stress and apoptosis in vitro and in vivo. Journal of Biochemical and Molecular Toxicology, 2004, 18(5), 261-272.

[18] L. Pari, and M. Latha, Effect of Scoparia dulcis (Sweet Broom weed) plant extract on plasma antioxidants in streptozotocin-induced experimental diabetes in male albino Wistar rats. Die Pharmazie, 2004, $59,557-560$.

[19] A.H. Zulfiker, M.R. Saha, S. Sarwar, L. Laizuman Nahar, K. Hamid, M.S. Sohel Rana, Hypoglycemic and in vitro antioxidant activity of ethanolic extracts of Ficus racemosa Linn. fruits. American Journal of Scientific and Industrial Research, 2010, 2(3): 391-400.

[20] F.J. Evans, Constituents of Egyptian Euphorbiaceae. IX. Irritant and cytotoxic ingenane esters from Euphorbia paralias L. Experientia, 1980, 36:12067.

[21] V.J. Navarro, J.R. Senior, Drug related hepatotoxicity. $N$ England Journal of Medicine, 2006, 354:731-739.

[22] A.Y. Onaolapo, O.J. Onaolapo, T.J. Mosaku, O.O. Akanji, O. Abiodun, A histological study of the hepatic and renal effects of subchronic low dose oral monosodium glutamate in Swiss albino mice. British Journal of Medical Research.2013,3(2):294-306.

[23] D. Lorke, A new approach to practical acute toxicity testing. Archives of Toxicology, 1983, 54: pp 275-287.

[24] Evenson M.E. "Spectrophotometric Technique". In: Tietz Textbook of Clinical Chemistry, 3rd ed, CA Burtis, ER Ashwood, Eds. Philadelphia: WB Saunders Co., 1999, pp. 75-93.

[25] J. Ochei and A. Kolhatkar, Textbook of Medical Laboratory Technology- Theory and Practice, $3^{\text {rd }}$ ed. 2008, Tata McGraw-Hill Publishing Company Limited, New Delhi: pp.180-182.

[26] A.C. Adebajo, O.F. Ayoola, E.O. Iwalewa, A.A. Akindahunsi, N.O Omisore, C.O. Adewunmi, Anti-trichomonal, biochemical and toxicological activities of methanolic extract and some carbazole alkaloids isolated from the leaves of Murraya koenigii growing in Nigeria. Phytomedicine. 2006, 13(4):246-254.

[27] E.S. Orhue, M. Idu, J.E. Ataman, L.E. Ebite, Haematological and histopathological studies of Jatropha tanjorensis (J.L. Ellis and Soroja) leaves in rabbits. Asian Journal of Biological Sciences. 2008, 84-89.

[28] T.O. Elufioye, O.I. Alatise, F.A. Fakoya, J.M. Agbedahunsi, P.J. Houghton, Toxicity studies of Tithonia diversifolia A. Gray (Asteraceae) in rats. Journal of Ethnopharmacology,2009, 122 (2):410415.

[29] D.E. Cross, R.M. Mcdevitt, K. Hillman, T. Acamovic, The effects of herbs and associated oils on performance, dietary digestibility and gut microflora in chickens from 7-28 days of age. British Poultry Science. 48, pp 496-506.

[30] S. Saeidnia, A.R. Gohari, N. Mokhber-Dezfuli, F. Kiuchi, Phytochemistry and medicinal properties of the genus Achille, DARU Journal of Pharmaceutical Sciences, 2011, 19 (3) 173-186.

[31] M. Nematy, S.A.R. Mohajeri, S.A. Moghadam, M. Safarian, A Noroway, S.M.R. Parizadeh et al., Nutritional status in Intensive Care Unit patients: a perspective clinical, pilot study. Medical Journal of Nutrition and Metabolism, 2012, pp. 163-168.

[32] T. Sanchez-Elsner, J.R. Ramirez, F. Rodriguez-Sanz, E. Varela, C. Bernabew, L.M. Botella,A cross talk between hypoxia and TGF-beta orchestrates erythropoietin gene regulation through SPI an SMADS Journal of Molecular Biology,2004, 36: 9-24.

[33] H.G. Olson, D. Bentton, K. Robinson, K. Thomas, A. Monro, A. et al., Concordance of the pharmaceutical in humans and in animals Regulatory Toxicology and Pharmacology, 2000, 32: 56-67.

[34] L. Tedong, P.D.D. Dzeufiet, E.A. Dimo, S. N. Asongalem, J.F. Sokeng, Flejou, P. Callard, and P.K Kamtchouing, Acute and subchronic toxicity of Anacardium occidentale Linn (Anacardiaceae) leaves hexane extract in mice. African Journal of Traditional, Complementary and Alternative Medicine, 2007, 4 (2):140-147.

[35] V.J. Navarro, J.R. Senior, Drug related hepatotoxicity. New England Journal of Medicine. 2006, 354:731-739.

[36] A. Kumar, N. Rai, N. Kumar, P. Gautam, J.S. Kumar, Mechanisms involved in hepatoprotection of different herbal products: a review. 
International Journal of Research in Pharmaceutical Science.2013, 4(2):112-117.

[37] J. Ochei and A. Kolhatkar, Textbook of Medical Laboratory Technology- Theory and Practice, $3^{\text {rd }}$ ed. 2008, Tata McGraw-Hill Publishing Company Limited, New Delhi: pp.159-160.

[38] A.F. ElGazar, A.A. Rezq, and H.M. Bukhari, Anti-hyperglycemic effect of saffron extract in alloxan-induced diabetic rats. European Journal of Biological Sciences, 2013, vol.5, pp.14-22.

[39] M.A. Ferguson, V.S. Vaidya, J.V. Bonventre, Biomarkers of nephrotoxic acute kidney injury. Toxicology, 2008 245:182-193.

[40] M.A. Perazella, Renal vulnerability to drug toxicity. Clinical Journal of American Society of Nephrology.2009, 4:1275-1283.

[41] S. Karie, V. Launay-Vacher, G. Deray, C. Isnard-Bagnis, Drugs renal toxicity. Journal of Nephrology and Therapeutics;2010, 6(1):58-74

[42] A. Gnanamani, M. Sudha, G. Deepa, M. Sudha, K. Deivanai, S. Sadulla, 2008, Hematological and biochemical effects of polyphenolics in animal Full L e $\mathrm{n} g \mathrm{t} \mathrm{h} \mathrm{R}$ e s e a r c h Paper models. Chemosphere, $72 ; 1321-1326$

[43] J.T. Mukinda, F.K. Eagles, Acute and sub-chronic oral toxicity profile of the aqueous extract of Polygala fruticosa in female mice and rats. Journal of Ethnopharmacology, 2010, 128; 236-240.
[44] E. Hecker, New toxic, irritant and cocarcinogenic diterpenoids esters from Euphorbiaceae and from Thymelaeaceae. Pure and Applied Chemistry; 1977, 49:1423-31.

[45] M.D. Sayed, A. Rizk, F.M. Hammouda, M.M. El- Missiry, E.M Williamson, F.J. Evans, Constituents of Egyptian Euphorbiaceae. IX Irritant and cytotoxic ingenane esters from Euphorbia paralias $L$. Experientia, 1980, 36:12067.

[46] A. Akintonwa, O. Awodele, G. Afolayan, H.A.B. Coker, Mutagenic screening of some commonly used medicinal plants. Journal of Ethnopharmacology. 2009, 125:461-470.

[47] G.O. Oze, H.U. Nwanjo, G.O. Onyeze, Nephrotoxicity caused by the extract of $A$. boonei (De Wild) stem bark in guinea pigs. International Journal of Nutrition and Wellness; 2007, 3:2.

[48] O. Awodele, V.O. Osunkalu, O.R. Akinde, J.A. Teixeira da Silva, W.O. Okunowo, E.C. Odogwu, et al. Modulatory roles of antioxidants against the aqueous stem bark extract of Alstonia boone (Apocynaceae)-induced nephrotoxicity and testicular damage. International Journal of Biomedical and Pharmaceutical Science 2010, 4(2):76-80. 